\title{
Groundwater modelling for need assessment of command scale conjunctive water use for addressing the exacerbating irrigation cost inequities in LBDC irrigation system, Punjab, Pakistan
}

\author{
Muhammad Basharat ${ }^{1,2} \cdot$ Ata-ur-Rehman Tariq $^{2}$
}

Received: 2 February 2015/Accepted: 26 March 2015/Published online: 9 April 2015

(C) Springer International Publishing 2015

\begin{abstract}
Bari Doab on Pakistan side of the border, about $29,000 \mathrm{~km}^{2}$, is one of the most productive agricultural regions in the Sub-continent. The surge in population has increased the competition for available water resources. Ensuing to this, a number of irrigationrelated issues have gained prominence. Effects of increasing climate aridity towards lower part of Bari Doab have emerged in the form of accelerated groundwater depletion. Lower Bari Doab Canal (LBDC) command, lying in the centre of Bari Doab, faces maximum spatial climate variability across its command area. This is the first model-based study of the long-term irrigation cost inequities due to successively increasing groundwater depletion towards the tail end. In the model, total water requirements of a grid cell are withdrawn from surface and/or sub-surface sources, based on rainfall and canal water availability. Groundwater pumping estimation is the most complex parameter; crop water deficit approach was adopted for the purpose. Due to excessive groundwater depletion, a tail-end farmer currently incurs 2.19 times higher irrigation costs as compared to the head-end counterpart. An additional depletion of $8-11 \mathrm{~m}$ is expected in the lower half of the command till 2031, in
\end{abstract}

Muhammad Basharat

basharatm@hotmail.com

Ata-ur-Rehman Tariq

atatariq@yahoo.com

1 International Waterlogging and Salinity Research Institute (IWASRI), WAPDA, Lahore 53700, Pakistan

2 Centre of Excellence in Water Resources Engineering (CEWRE), University of Engineering and Technology (UET), Lahore 54890, Pakistan contrary to stable conditions in head end. As a result this irrigation cost anomaly is simulated to be further aggravating to 2.36 times in year 2031. Thus, irrigation systems with significant spatial climate variability need appropriate command scale conjunctive management of surface and groundwater by the concerned irrigation planning and management agencies. This would help in plummeting the exacerbating irrigation inequities by reducing waterlogging and groundwater depletion.

Keywords Conjunctive use - Groundwater modelling · Aquifer mining $\cdot$ LBDC $\cdot$ Irrigation cost $\cdot$ Equity $\cdot$ IBIS

\section{Introduction}

Triggered by the shortage of canal water supplies, particularly during drought period (1999-2002), groundwater resources development started with an accelerated pace, especially in the Punjab part of Indus basin irrigation system (IBIS). Now, farmers rely increasingly on tubewell water, especially at critical time of crop requirements. These increasing crop water requirements due to ever increasing population have shifted the dependence from canal supplies (at the time of irrigation system design) to both the canal water supply and groundwater pumping, nowadays. Replenishment of groundwater also relies on canal water seepage and rainfall recharge. But seepage to groundwater from surface resources is variable, both in space and time, due to variability in rainfall and proximity to surface flows. This has created a situation where integrated use of all the water sources, i.e., rainfall, canal and groundwater, has become an important aspect in order to sustain the present agricultural growth and production. 


\section{Changing groundwater regime and emerging challenges}

The cropping intensity was $102.8,110.5$ and $121.7 \%$ during 1960, 1972 and 1980, respectively (Ahmad 1995), now operating at about $172 \%$ (Mirza and Latif 2012) and even higher in certain areas. As a result, groundwater mining, due to higher abstraction rates as compared to the corresponding recharge, is well reported in the literature (NESPAK 1991; Steenbergen Van and Olienmans 1997; Basharat and Tariq 2013a; Cheema et al. 2014; Basharat et al. 2014). Basharat and Tariq (2013a) have shown the ever rising aquifer levels till 1960, under LBDC irrigation system, since its inception in 1912, and the currently observed groundwater depletion during the last two decades (Fig. 1). According to Basharat et al. (2014), the gravity of drop in aquifer levels, as seen presently in central and lower parts of Bari Doab in Pakistan, has proved that irrigators are now facing an increased cost of pumping, in some areas they have to upgrade the pumping plant to cope with higher lifts. The time is approaching fast when groundwater may become out of reach of small/poor farmers. The paper pointed out a depletion rate of $0.55 \mathrm{~m}$ per year for the lower part of Bari Doab in contrary to stable groundwater levels in upper part.

Punjab Private Sector Groundwater Development Project (PPSGDP 2000) already pointed out that the areas with deeper groundwater levels are generally located towards tail reaches of the irrigation systems. Later on, Basharat (2012) demonstrated that towards tail ends there is a relatively increasing shortfall between crop water requirement and irrigation water supply in comparison to head ends of irrigation systems. The reason is that spatial climate variability within the irrigation system in the Indus Basin has created differential variations in rainfall and as a result, in irrigation water demand. With dramatic increase in the intensity of groundwater exploitation in the last three decades, the policy landscape for Pakistan has changed. Now, the issue is to avoid declining groundwater tables and deteriorating groundwater quality in fresh groundwater areas to ensure equal access to this increasingly important natural resource. Consequently, capital cost of tubewell installation as well as groundwater pumping is increasing, and this has been observed for the lower parts of the Bari Doab. Tail-end areas of LBDC command are also facing successively increasing depth to groundwater (Basharat and Tariq 2013a). Shah (2006) mentioned these issues as a key challenge by saying 'sustaining the massive welfare gains, groundwater development has created without ruining the resource is a key water challenge facing the world today'.

\section{Study area description}

Bari Doab (lands between Ravi and Sutlej rivers) on Pakistan side of the border covers about $29,000 \mathrm{~km}^{2}$, which is one of the most productive agricultural regions in the Subcontinent. LBDC irrigation system falls in the centre of the Bari Doab (Fig. 2), with a gross command area (GCA) of 0.80 million hectares (Mha). The main canal with a design discharge of $278 \mathrm{~m}^{3} / \mathrm{s}$ offtakes from the left bank of Ravi River at Balloki barrage; flows for $201 \mathrm{~km}$ supplying water to its 65 Nos. distribution channels. These consist of $53.5 \mathrm{~km}$ branch canals and $2261 \mathrm{~km}$ of distributaries, minors and sub-minors. The canal irrigation is managed through four irrigation administrative divisions i.e., Balloki, Okara, Sahiwal and Khanewal (Fig. 2). Agriculture in the area is sustained through surface water supplies in the LBDC and pumped groundwater from the underlying unconfined aquifer. The canal water supply is the most important, least costly and dependable prime water resource, both for crop water requirement and groundwater recharge,
Fig. 1 One century groundwater levels, showing aquifer filling and depletion under LBDC (observation well locations shown in Fig. 2)

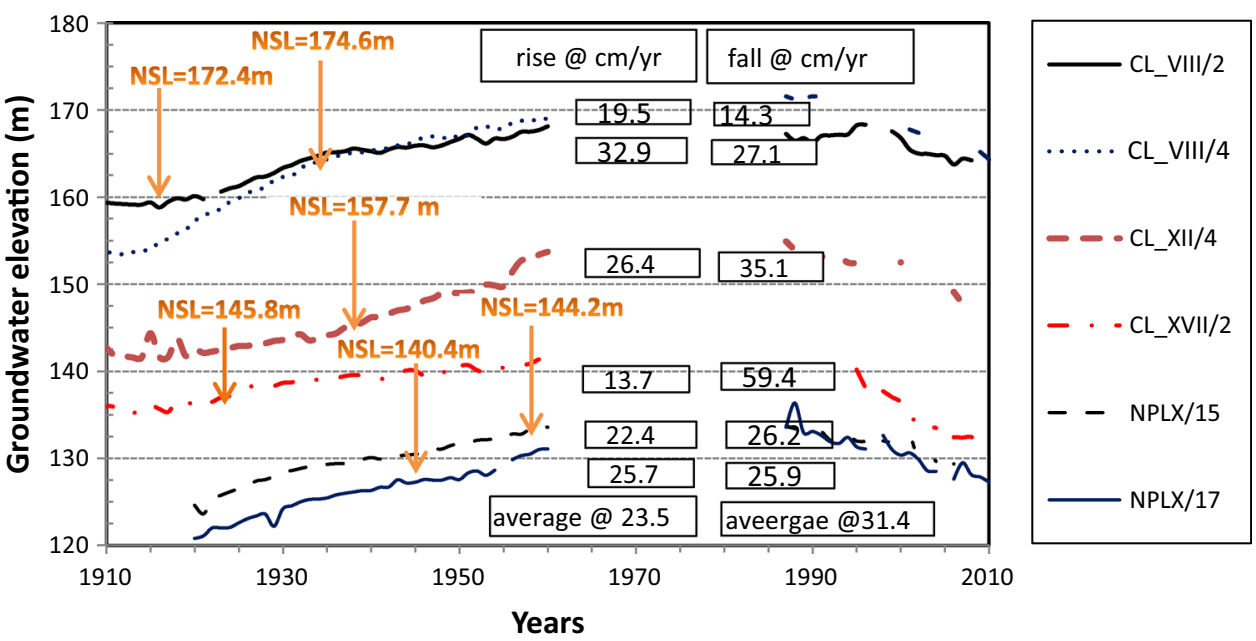


Fig. 2 LBDC irrigation command in Bari Doab, with its canal network, irrigation administrative divisions and assumed eight hydrologically similar units $(H S U s)$ in the area

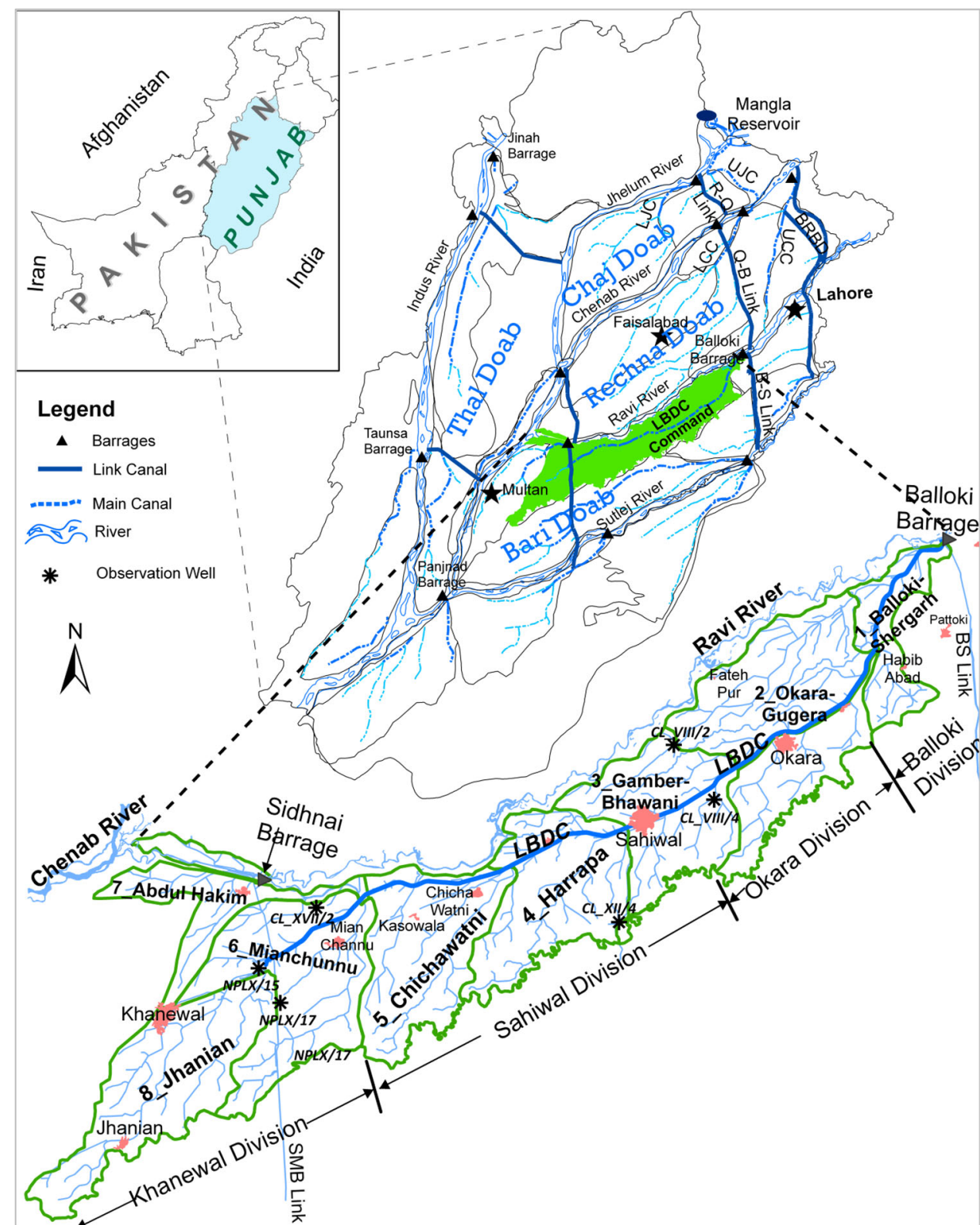

with recent average annual (2001-11) deliveries of about 4897 million cubic metres (MCM) at canal head. Constructed in 1911-13, the irrigation system was designed for a cropping intensity of $67 \%$, which has steadily increased to the present level of about $160 \%$. However, the sustainability of this increased food security is most importantly linked to the sustainability of the groundwater reservoir.

\section{Physiographic Features, Soils and the aquifer}

The area is part of a vast stretch (about $10,000 \mathrm{~km}^{2}$ ) of alluvial deposits worked by the tributary rivers of the Indus i.e., the Ravi and the Sutlej rivers. The general slope of the area is mild, towards the South-West direction (tail end), with an average ranging from 1 in 4000 to 1 in 10,000. The area consists of two distinct physiographic/landform units i.e., the Bar upland (high elevation area) in the upper half of command and the abandoned flood plain (Ravi and Sukh-Beas) area (towards tail end), separated mostly by a sharp river cut escarpment locally known as "Dhaya". The soils of the Bar upland are of brighter colours (mostly silty), deeply developed and show definite profile development (horizons). The soils of the abandoned flood plain are characterised by greyish colours, with weak or little profile development in the sub-soil and layers of different textures in the substratum.

The alluvial sediments comprising the aquifer exhibit considerable heterogeneity, both laterally and vertically. 
Despite this, it is broadly viewed as a single contiguous, unconfined aquifer. Study of the lithologic $\operatorname{logs}$ of test holes (180-300 m depth) and test tubewells (30-110 m depth) indicates that Bari Doab consists of consolidated sand, silt and silty clay, with variable amounts of kankers. The sands are principally grey or greyish-brown, fine to medium grained. Very fine sand is common, finer grained deposits generally include sandy silt, silt and silty clay with appreciable amounts of kanker and other concretionary material. Re-evaluation of the original data (WAPDA 1980a) and geological sections (United States Department of the Interior 1967) suggests that in the area between Balloki and Okara, there are moderately persistent and alternate layers of finer materials (clay and silt) of thickness of about $15-30 \mathrm{~m}$, without any regularity/continuity. The layer of clay/silt near the surface, $6-15 \mathrm{~m}$ thick, is also prominently evident. However, thick layers ( $40 \mathrm{~m}$ of very fine to medium sand) were also found at deeper depths of the aquifer. Within the Middle Zone, silt/clay layers tend to be thinner and distributed unevenly, both vertically and horizontally. More importantly, the aquifer characteristics tend to be very much sandy towards Harappa town. Also, lithologic logs of bore holes on left side of LBDC canal show sandy aquifer without any marked clay layers. The lower zone, as represented by the cross section near Mian Channu, appears to be as described above, with a greater predominance of sand, and rare clay/silty materials. Gravels of hard rock are not found within the alluvium and coarse or very coarse sands are uncommon.

\section{Spatial climate variability across the area}

Aridity of the climate increases towards south in Punjab, as is evident from rainfall comparison in Fig. 3 for three meteorological stations (Lahore, Faisalabad and Multan,

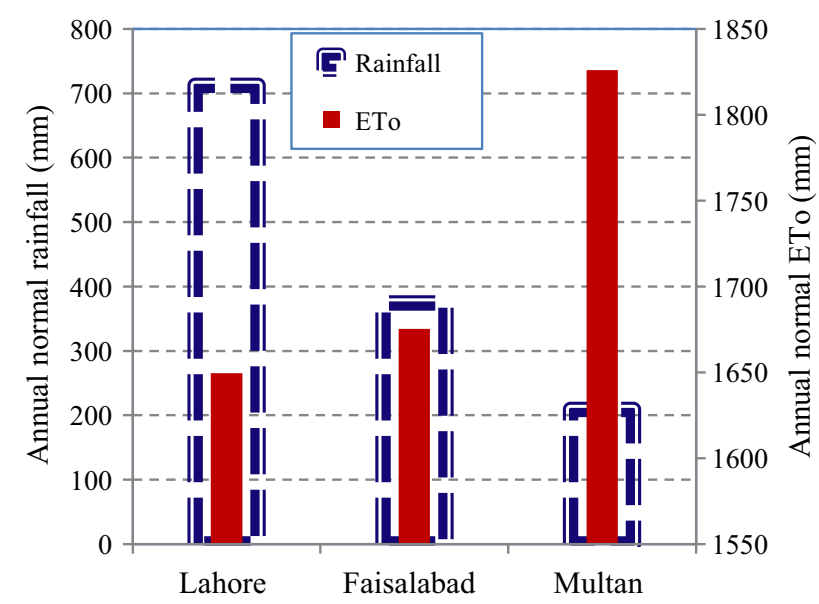

Fig. 3 Increasing aridity towards South, shown by met stations in Punjab (Basharat and Tariq 2013a) shown in Fig. 2). Consequently, demand for supplemental irrigation supplies increases towards south in downstream direction of canal systems in IBIS, particularly in upper and central parts of Punjab province. Cheema et al. (2014) applied SWAT model to derive the total annual irrigation requirement, groundwater pumping and depletion in the irrigated areas of the Indus Basin, for the year 2007, the results also revealed increasing rates of groundwater pumping and depletion towards the lower parts of Bari Doab. According to Basharat and Tariq (2013a), spatial climate variability within the irrigation system in the Indus Basin has created differential variations in rainfall and as a result, in irrigation water demand. For the LBDC irrigation system, it was established that annual normal rainfall decreases towards tail $(212 \mathrm{~mm})$ as compared to head $(472 \mathrm{~mm})$. It was also pointed out that groundwater table depletion rate is highest $(0.34 \mathrm{~m} /$ year $)$ in Khanewal Division, the tail reach of LBDC command, followed by Sahiwal Division $(0.18 \mathrm{~m} /$ year), whereas the groundwater levels in Balloki and Okara Divisions (upper reaches) are stable.

\section{Canal and groundwater use in the LBDC command}

Canal water supplies are managed more or less equitably by the irrigation department, till the watercourse head. However, groundwater is pumped by the farmers, according to their needs and wills. Basharat (2012) analysed canal and groundwater use (2008-09) by the farmers in four selected watercourses in the LBDC command, on Kharif (April-September) and Rabi (October-March) 2008-09 (Fig. 4). Total water usage (canal and ground water) is more or less equitable from head to tail of the command. Looking separately at canal withdrawals by the watercourses, there is not any trend (decreasing or increasing) in the downstream direction. However, during Kharif season, tubewell water usage is highest for the upper reach areas due to watertable being shallow, low pumping cost and high delta crops. This is also supported by high density of tubewells and more rice cultivation in Okara Division as reported by NESPAK (2005).

\section{Equity issues for LBDC irrigation system}

Equity can be emphasized in a variety of different perspectives and scenarios, each dealing with specific situations i.e., (1) equity in distribution of available canal water; and (2) equity in meeting crop water demands (in relative terms) under varying crop water requirements due to variability of ETo and rainfall in the irrigation command area. Inherent in the system design and the current irrigation operations scenario, "equity in irrigation water distribution is considered to have been attained when the 
Fig. 4 Water usage at watercourse level of four watercourses during 2008-09 (Basharat 2012)

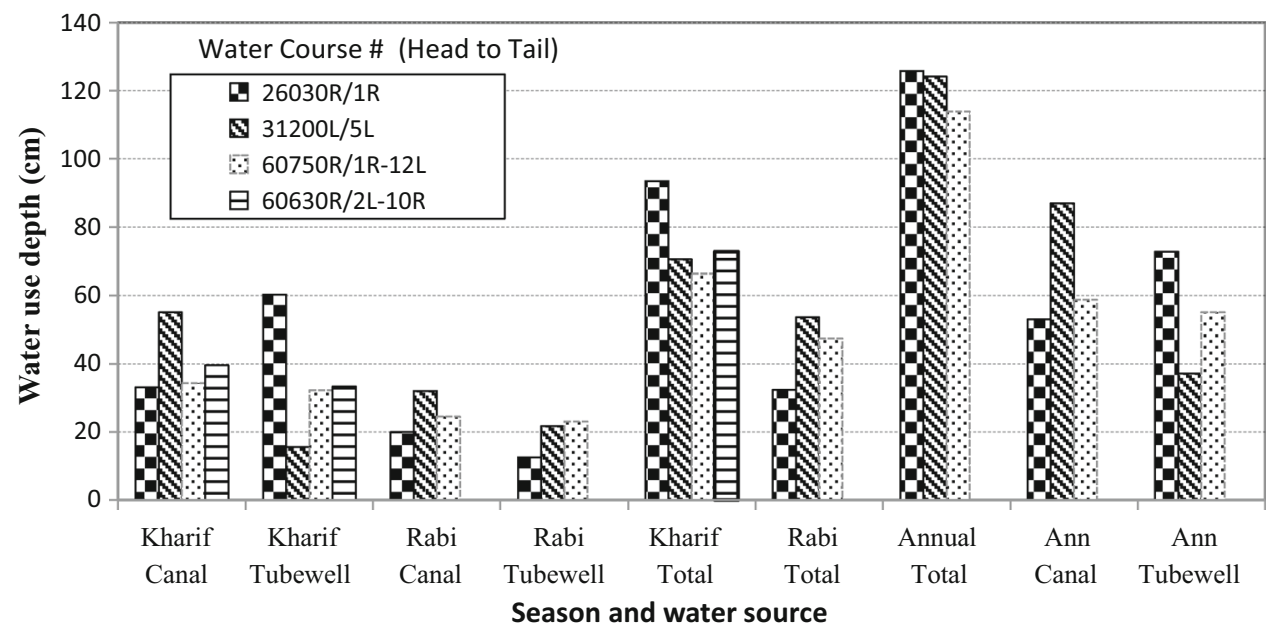

amount of water distributed to every outlet along a distributary is in proportion to the outlet's design discharge that approximately matches the proportion of water delivered at the distributary head to its design discharge" Bhutta and Vander Velde (1992).

Presently, water allowance within the study area is 3.33 cusecs per 1000 acres, designed and operated to achieve equity in conveying canal water up to outlets in the command area, irrespective of the variation in rainfall and groundwater depth. Basharat and Tariq (2013b) analysed 4 years data (2006-2009), collected by project monitoring and implementation unit (PMIU) of Punjab irrigation and power department, about discharges at head of the channels offtaking from the LBDC main canal. Average values of delivery performance ratio (DPR) for a period of 4 years (2006-2009) for these channels were 0.75, minimum and maximum DPR of 0.53 and 0.96 , respectively, standard deviation of 0.08 and coefficient of variation as 0.11 . Mean canal water diversions (depth distributed over CCA of respective channels) were 65.74 and $65.14 \mathrm{~cm}$, for the years 2006 and 2007, respectively, with corresponding standard deviation of 10.3 and $11.3 \mathrm{~cm}$ and coefficients of variation as 0.16 and 0.17 , respectively. It was concluded that the inequity in surface water diversion amongst the offtaking channels was prevalent, but without any trend in head-tail end direction. According to Basharat (2012) current significant threats to groundwater irrigation in LBDC command are as follows:

- Increased waterlogging in head end of the command during periods of enough canal supplies and relatively higher rainfall;

- Higher groundwater depletion rates towards the tail end of the command, thus an increase in pumping costs with passage of time; and

- Drawing down the aquifer is a significant economic issue for the tail-end farmers-as it is eliminating access to users of shallower pump sets (centrifugal pumps) and poor stake holders who are unable to invest in pumping deep groundwater.

Thus, the reasons for excessive groundwater depletion towards the tail end and its likely extent in future are the important questions. In this paper, we highlight head-tail end total irrigation cost differences at the year 2011, and 20 years thereafter, for the LBDC command, using groundwater simulation approach, assuming that current equitable irrigation water supply would entail in the future.

\section{Materials and methods}

The LBDC command was divided into eight sub-units called Hydrologically Similar Units (HSUs) as shown in Fig. 2. These HSUs were digitized in GIS in consideration of distributary command boundaries. Although, aridity of the climate increases continuously towards downstream of the command area, yet the calculations regarding crop water requirement, rainfall, irrigation supplies, and groundwater recharge and pumping, were lumped over the respective HSU area. The details of variation in these hydrological parameters and computation of crop water requirements for the respective HSUs can be seen in Basharat and Tariq (2013b).

\section{Groundwater data and recharge analysis}

The data regarding depth to watertable since 1987 were analysed and data discrepancies were removed by plotting hydrographs of historic depth to watertable data. The observation points were marked in GIS of the LBDC command. The depths to watertable values were converted to groundwater elevations using actual survey data or shuttle radar topography mission (SRTM) elevation 
data with $90 \mathrm{~m}^{2}$ resolution (where the actual survey was not available). The maps of depth to groundwater and elevation contours were prepared using Surfer software and converted to GIS format.

The recharge to groundwater in the area is occurring from canal network seepage, watercourse and field application losses, and rainfall. The recharge rates were assessed on HSU basis as follows.

\section{Canal network seepage}

PPSGDP (1998) made an extensive analysis of seepage rates from a wide ranged capacity of canals in Pakistan. Seepage rates adopted therein for different channel capacities were used for this study. The data about hydraulic parameters i.e., design discharge, full supply level, flow depth and bed level of all the LBDC system available in GIS format were used. The database file was imported in Excel and seepage losses were computed for each channel reach based on its wetted perimeter and corresponding seepage rates i.e., cusecs per million square feet (cfs/msf). The computed results were imported into the GIS database shape file, and the total seepage rate (cusecs) from the channel network within each HSU was determined using quarry and analysis techniques in GIS. To account for partial flows and canal closure in the LBDC system, the daily flow volumes of LBDC canal for the period 2006-08 were compared to the maximum possible flow volumes, assuming LBDC drawing its maximum discharge without any closure. The ratio of the actual volume of water diverted to that of assumed full capacity without closure was determined and found to be 0.7176 . Calculated seepage rates for each HSU were corrected by multiplying with this ratio.

\section{Watercourse and field application losses}

Seepage rate from LBDC irrigation system network was $44.53 \mathrm{~m}^{3} / \mathrm{s}$ (1572.6 cfs), which is $18.72 \%$ of current maximum discharge of LBDC canal. Annual average diversions to LBDC (2001-09) were reduced by $18.72 \%$ for calculating water availability at watercourse head. For the water diverted to watercourse head, $25 \%$ was adopted as seepage losses within the watercourse (before entering farm gate) and $80 \%$ of this assumed as recharge to groundwater (WAPDA 1980a). The irrigation application efficiency at the farm level was considered to be 80 and $75 \%$ of this was taken as recharge to the groundwater (WMED 1999). The total recharge to groundwater from watercourse and field application is $31.25 \%(20+11.25)$ of that diverted to watercourse head.

\section{Rainfall recharge}

Ahmad and Chaudhry (1988) reported the rainfall recharge to groundwater as calculated in revised action program (RAP) using Massland's approach for the year 1977-78 for all the canal commands in Punjab province. In this method, the condition of land such as fallow, recently irrigated area, within the middle of irrigation interval and that just before the next irrigation are identified as factors affecting the recharge. The groundwater recharge reported therein for irrigated areas in Punjab was calculated as a percent rainfall recharge $\left(R_{\mathrm{r}}\right)$ of total annual rainfall $(R)$ in inches. A straight line Eq. (1) was fitted to indicate relationship between rainfall recharge $(\%)$ to groundwater and the total rainfall. Recharge to groundwater from rainfall was found to be varying from 14.3 to $21.05 \%$ of the total rainfall.

$R_{r}=0.1584 \times R+14.29$

where, $R_{\mathrm{r}}$ is the rainfall recharge as $\%$ of total annual or seasonal rainfall $(R)$.

\section{Groundwater model development}

The aquifer under LBDC irrigation system is characterised by its unconfined behaviour i.e., water is derived from storage by drainage of pores, expansion of water and compaction of aquifer matrix. The watertable location in the aquifer is space and time dependent due to its unsteady state nature as result of varying recharge and discharge rates both with respect to location and time. Most of the aquifer water is discharged by pumping out for irrigation. Surface water is added to the unconfined aquifer through seepage from canals, watercourse and field irrigation losses or by surface infiltration due to rainfall events. For heterogeneous, anisotropic conditions, the general equation governing unconfined three-dimensional flow is as given below:

$$
\begin{aligned}
& \frac{\partial}{\partial x}\left(K_{x} h \frac{\partial h}{\partial x}\right)+\frac{\partial}{\partial y}\left(K_{y} h \frac{\partial h}{\partial y}\right)+\frac{\partial}{\partial z}\left(K_{z} h \frac{\partial h}{\partial z}\right)-R \\
& \quad=S_{\text {уа }} \frac{\partial h}{\partial t}
\end{aligned}
$$

where $R=R(x, y, z, t)$ is the recharge volume per unit aquifer volume (actually net of point recharge and discharge) at the point $(x, y, z)$ at time $t$ and have dimensions of $\mathrm{T}^{-1}, h=$ potential over the flow domain and $K_{x}, K_{y}$, $K_{z}=$ hydraulic conductivity in the $x, y$ and $z$ directions and $S_{\text {ya }}$ is specific yield of the aquifer.

\section{Space and time discretization}

A uniform grid with $500 \mathrm{~m}$ spatial resolution in both of the horizontal directions was superimposed on the LBDC command, resulting in 138 rows and 515 columns. A total 
depth of $200 \mathrm{~m}$ was modelled with five layers. Thus, a uniform grid resolution of $500 \mathrm{~m}$ square covers an area of $250,000 \mathrm{~m}^{2}$ (25 ha) with 31,498 active cells per model layer. The model was calibrated and validated for transient conditions from Kharif 2001 to 2009 with two stress periods each year i.e., Kharif (183 days) and Rabi (182 days). Each stress period had ten time steps with a time-step multiplier of 1.2 to characterize the temporal variation in piezometric heads. Pumping from irrigation wells installed by farmers and recharge in the form of seepage from canal irrigation network and watercourses, along with field irrigation losses and rainfall recharge, were the major stress components in the model. The top surface elevation of Layer 1 was modelled using a $90 \mathrm{~m}$ resolution digital elevation model obtained from SRTM data. The bottoms of Layers 1 through five were specified by subtracting fixedincrement distances from the top of Layer 1, creating layers with constant thickness that follow topography.

\section{Aquifer parameters}

As reported by Bennett et al. (1967), the alluvial sediments that comprise the aquifer exhibit considerable heterogeneity, both laterally and vertically. Lithological data of test holes (WAPDA 1980b), about 64 falling in LBDC command, were used to estimate $K$ values, based on the average strata of material found in each layer and the values reported in literature for these material (Ritzema 1994, Table $7.2 \mathrm{p} 237$ ). Hydraulic conductivity contours so obtained for the model layers were interpolated in GV 5 for values in individual cells of the model. Also, the specific yield values for these materials were selected from the curve developed by the US Army Corps of Engineers (1999).

\section{Model domain/boundaries}

LBDC command boundary (except the Koranga Feeder command area, being on other side of the Ravi River) was used to develop the model boundary as shown in Fig. 5. All the cells falling out of this boundary were declared as noflow cells, with the exception of locations where transboundary flows were represented with a general head boundary (GHB) condition using GHB package. These locations include certain reaches of the Ravi River falling below Balloki Barrage and both upstream and downstream of Sidhnai Barrage, due to ponding of surface water for diversion into Sidhnai-Mailsi-Bahawal (SMB) link canal. Other locations were southern and South-western, eastern and South-eastern boundaries, where regional groundwater flows out or in of the canal command boundary. The groundwater levels observed adjacent to these boundaries were employed for calibration. Conductance was changed during model calibration to incorporate the flow across the boundary.

\section{Tubewell pumpage estimation}

One tubewell was placed per nine model cells. Estimation of groundwater pumping in large irrigated areas is mostly based on the number of tubewells, pump capacity, and operational hours (NESPAK/SGI 1991; Maupin 1999; Qureshi and Akhtar 2003; Kumar et al. 2009). Operational hours can be based on field survey or from electricity/fuel usage. This type of estimation cannot be preferred where these estimates are required as time series consisting of many years of simulation. Although, groundwater pumping estimates from field survey, for Kharif 2004 and Rabi 2004-05 (NESPAK 2005), were available, it was a rough estimation. Therefore, groundwater pumping estimates for different stress periods in the model were based on crop water deficit (CWD) approach, as was applied by Nels et al. (Nels et al. 2004) in California for estimating monthly and annual groundwater pumping for a semi-arid irrigated area.

Due to large variation in canal supplies and rainfall, the crop water deficit (CWD) varies much, seasonally as well as annually, and also spatially along the length of the

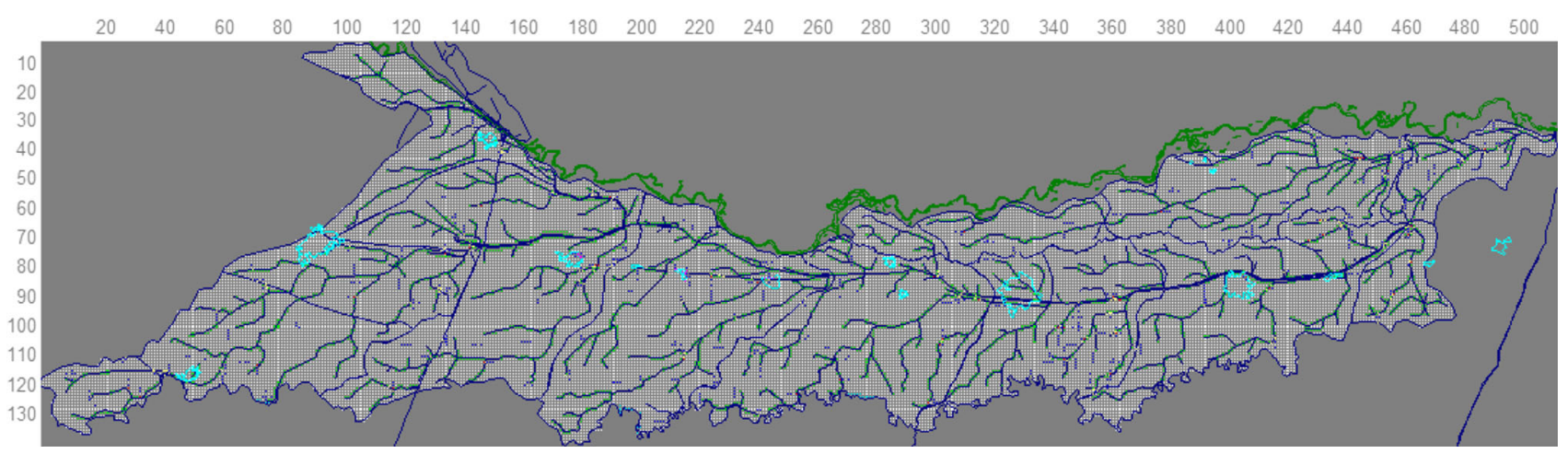

Fig. 5 Representation of model extent with active grid cells and canal system and HSUs superimposed, delineated in groundwater vistas 
command. Water available for crop consumptive use from irrigation diversions was taken as $48.77 \%$ of that diverted at canal head. The rainfall availability for crop consumptive use was based on effective rainfall $\left(R_{\mathrm{e}}\right)$, which was further reduced by subtracting part of it as recharge to groundwater. The $R_{\mathrm{e}}$ varied from 71.4 to $86.3 \%$ and part of it available for crop consumptive use was 54.5-72.3\% of the seasonal rainfall in head-tail end direction. The CWD in the form of crop consumptive use to be met by groundwater pumping was calculated for each stress period using the Eq. (3):

$\mathrm{CWD}_{i j}=\mathrm{ET} a_{i j}-\mathrm{CW}_{i j}-\mathrm{Re}_{i j}$

where, $\mathrm{CWD}_{i j}=$ crop water deficit to be met from groundwater pumping; $\mathrm{ETa}_{i j}=$ actual evapotranspiration requirement for all the crops commonly grown; $\mathrm{Cw}_{i j}=$ Canal water availability; and the subscripts $i$ and $j$ represent the HSU and stress period, respectively.

Another deficiency in estimating the groundwater pumping (GWP) based on CWD approach is the lumping of calculations over the whole stress period. Actually, during almost all the rainfall occurrences, some of the cropped fields will have to be applied with canal water, even if there is no irrigation demand for the crops due to the rainfall event which has occurred within the last 10 days. To cover such deficiencies in estimating GWP requirement, a hypothetical function was developed between GWP and CWD (Eq. 4, plotted in Fig. 6). Here, GWP is percentage function of CWD in respective HSU and stress period, which is a percentage of the maximum deficit (353 mm, found in Kharif 2009, for Jhanian HSU).

$\mathrm{GWP}_{i j}=-42.14 \ln \left(\mathrm{CWD}_{i j}\right)+267.31$

where, $\mathrm{GWP}_{i j}=$ Groundwater pumping as $\%$ age of CWD at $i$ th HSU during $j$ th stress period.

The developed curve as shown in Fig. 6 is the final version after its corroboration during calibration i.e., after varying and adjusting the maximum percentage of 200 and minimum percentage of 75 , in response to improvement in model calibration statistics. Actual groundwater pumping by the farmers was assumed to be responding to this crop water deficit on the basis of the following hypothesis:

- With increasing crop water deficit, the farmer responds by pumping groundwater which decreases asymptotically as a percentage of the maximum CWD, the maximum percentage of water deficit being met by groundwater pumping was estimated to be $75 \%$.

- When there is very little or even no CWD, farmers pump more than required i.e., the less the percentage CWD, the more is pumped in terms of groundwater pumping percentage, e.g., when CWD is $5 \%$, pumping is $200 \%$. This also happens due to the constraint of minimum irrigation application depth which cannot be less than $50-75 \mathrm{~mm}$ in basin/border irrigation system practised in the study area.

\section{Computation of irrigation costs}

For the purpose of groundwater pumping cost computations, average depth to groundwater was calculated for each of the HSU (Fig. 2), based on all model cells falling in it. The cost of groundwater pumping per year per hectare on HUS basis was calculated by multiplying average groundwater pumping volumes $\left(\mathrm{m}^{3} / \mathrm{ha}\right)$ required per year for the period of simulation and the corresponding cost of pumping $\left(\right.$ Rs. $\left./ \mathrm{m}^{3}\right)$ depending upon DTW in the HSU. The annual cost of canal water per hectare was calculated based on the existing prevailing flat Abiana (revenue) rates by the Punjab Government (Kharif Rs. 85/acre and Rabi Rs. 50/acre) which are imposed since Kharif 2003, (Sufi 2011). The total annual irrigation water cost accrued per hectare was obtained by summation of the cost of pumped ground and canal water.
Fig. 6 Groundwater pumping as a function of crop water deficit

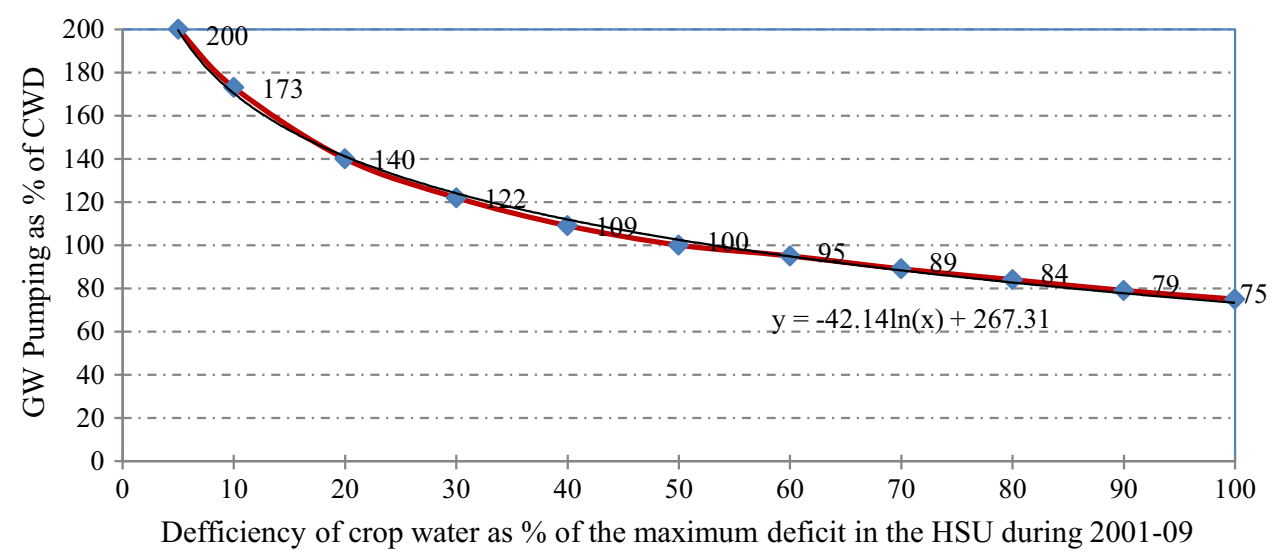

Defficiency of crop water as \% of the maximum deficit in the HSU during 2001-09 


\section{Results and discussions}

\section{Variation of groundwater recharge across the command}

The total groundwater recharge, along with its components i.e., canal network seepage, watercourse and field application losses and rainfall recharge, is shown in Fig. 7. It is seen that the irrigation network (main and secondary canals) seepage decreases from head to tail of the LBDC command. This is due to the decreasing density of the channels (main canal, branches and distributaries) and their discharges towards the tail of the irrigation system. The watercourse and field application losses joining to groundwater remain equitable with respect to headtail end perspective of the main canal. However, there is a possibility of minor variations in this recharge component but that too, within the HSUs, mostly due to local inequity at secondary level channels. This minor level local inequity is considered not to be adding towards anomaly in groundwater recharge in head-tail perspective of the canal command. The third component, rainfall recharge, decreases most significantly towards the tail end of the command. Groundwater recharge from canal supplies and rainfall recharge (excluding recharge from groundwater irrigation) reduces from $430 \mathrm{~mm}$ at head end to $285 \mathrm{~mm}$ at tail end. Thus, there is a significant reduction in recharge to groundwater, both from rainfall and canal network seepage. As a result, total recharge to groundwater from all the three components decreases significantly in the downstream direction of the command.

\section{Groundwater depth and elevation}

As a consequence of decreasing groundwater recharge in downstream direction, the depth to groundwater varies from 4 to $8 \mathrm{~m}$ in head end as compared to $14-20 \mathrm{~m}$ in tail end (Fig. 8a). The groundwater elevations in Fig. 8b show a steep groundwater gradient (1 in 3060) as compared to natural ground slope (1 in 3715). Also, groundwater depletion is taking place in the command but to different extents in different areas. According to Basharat and Tariq (2013b), the groundwater depletion rate was highest (0.34 m per year) in Khanewal Division, the tail reach of LBDC command, followed by Sahiwal Division $(0.18 \mathrm{~m}$ per year); whereas the groundwater levels in Balloki and Okara Divisions (upper reaches) were stable. On the contrary, higher groundwater depletion rates of $0.94 \mathrm{~m}$ per year in Okara division (head reach) during drought period (1998-2002) as compared to corresponding $0.53 \mathrm{~m}$ in middle and tail reaches (Sahiwal and Khanewal) reveal considerably higher contribution of rainfall towards crop consumptive use and groundwater recharge in head reach.

\section{Groundwater pumping cost inequity over the command}

Division-wise graphical presentation of average watertable depth and tubewell boring depth is shown in the Fig. 9. Cost of groundwater pumping with increase in depth to watertable has been estimated from data of drilling depth and pumping equipment, commonly used across the LBDC command, as reported by Halcrow (2006). According to the results, cost per cubic metre of groundwater pumped increases about 3.5 times as the depth to watertable drops from 6 to $21 \mathrm{~m}$ from head to tail in LBDC command (Fig. 10). Similarly, Qureshi and Akhtar (2003) point out that the cost of installing tubewell in areas where watertable depth is more than $24 \mathrm{~m}$ is seven times higher as compared to those areas where watertable depth is around
Fig. 7 Variation of groundwater recharge from head to tail of the command

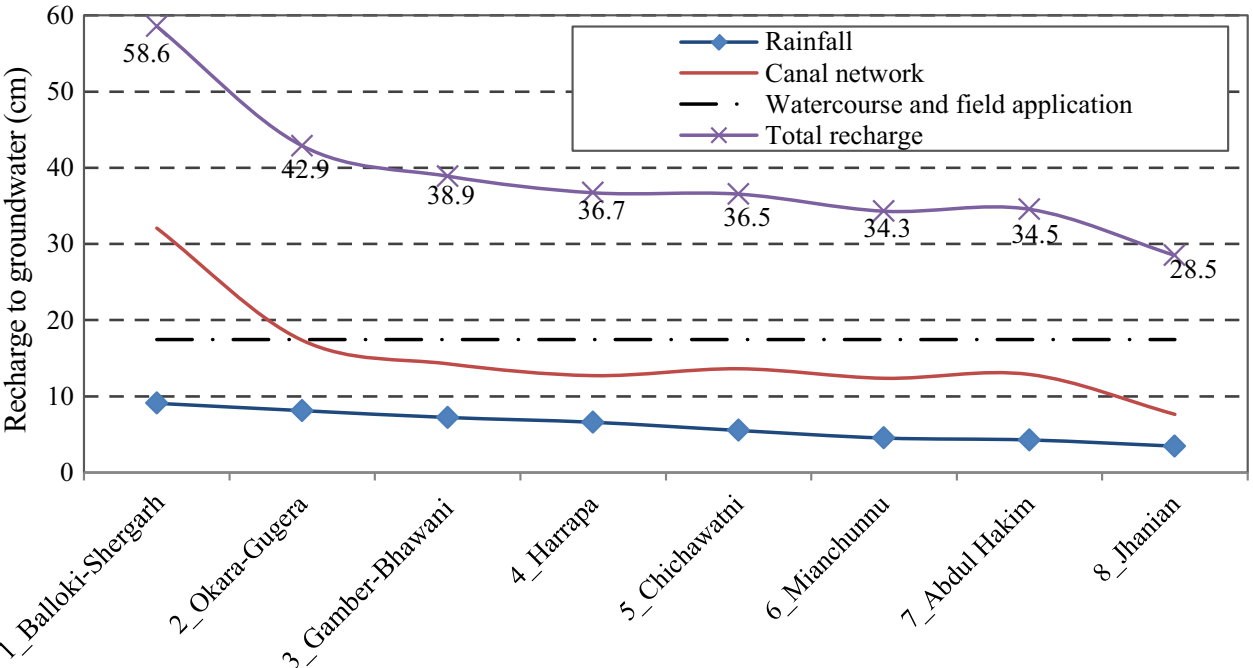

Hydrologically Similar Units 
Fig. 8 Depth to groundwater (a), and observed and calibrated model simulated groundwater elevations (b)

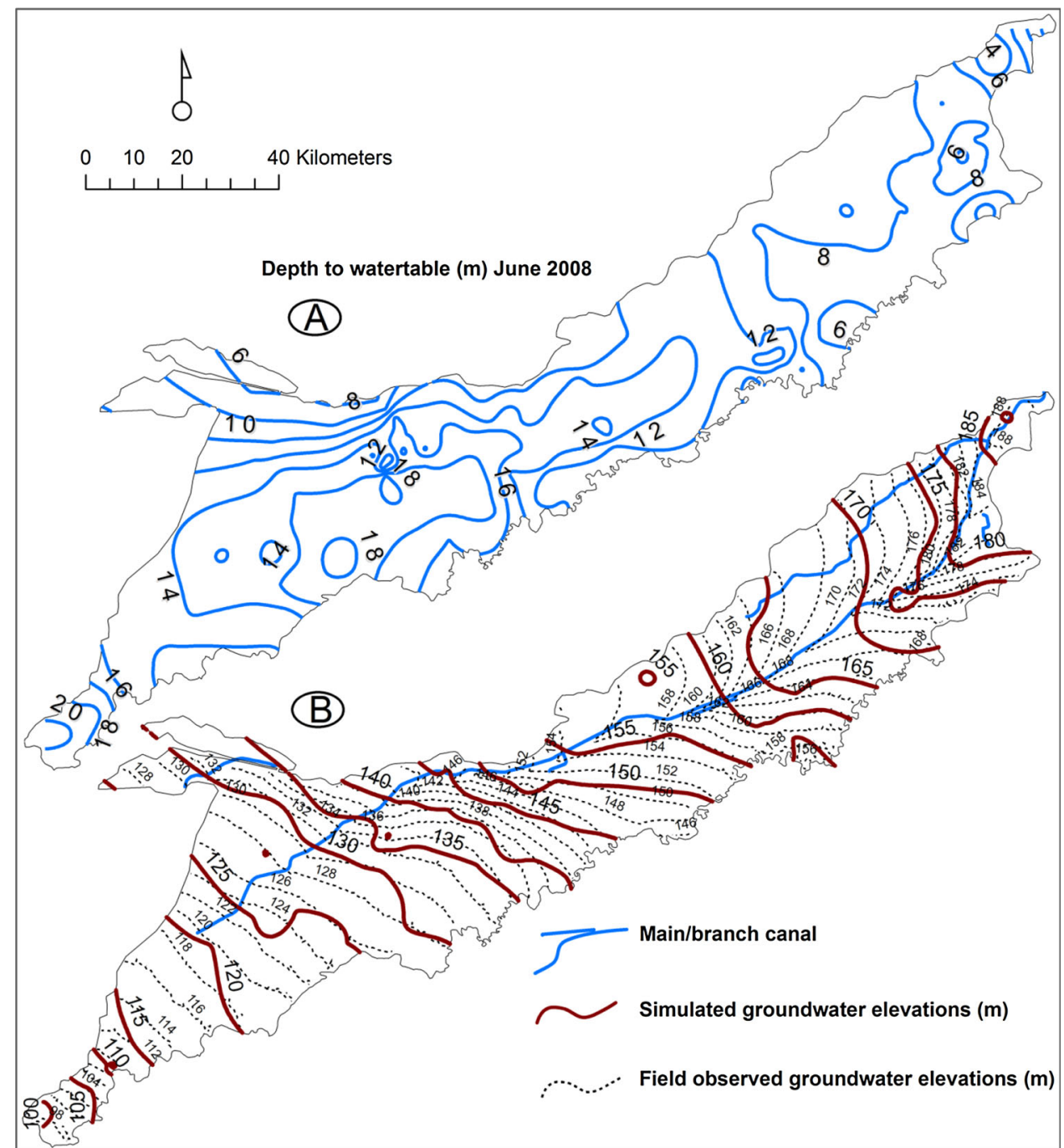

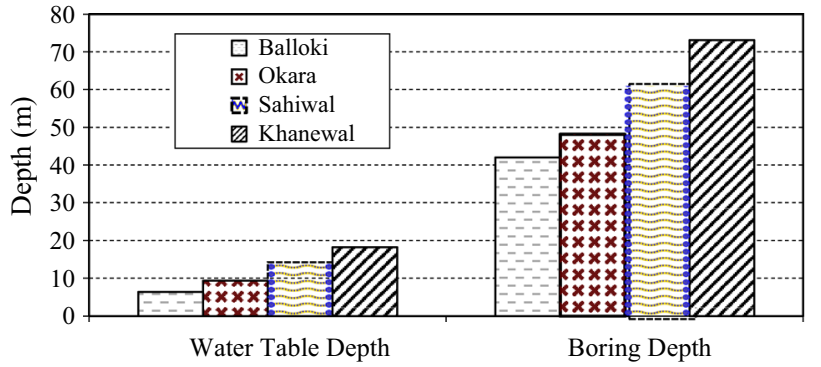

Fig. 9 Increasing DTW and boring depth towards tail of the LBDC command

$6 \mathrm{~m}$. Due to such extra ordinary cost differences regarding groundwater pumping, farmers suffer to different extents, depending upon their location (whether at head/middle/tail) of the main canal and/or watercourse. The fact that farmers located at upper reaches of the irrigation canals get higher income and it progressively decreases downstream along all main, secondary and tertiary irrigation canals has also been highlighted by Latif (2007) and Latif and Ahmad (2009). According to Hussain (2005), tail-end farmers, often the poorest, suffer a twin disadvantage-less water and more uncertainty. Poverty among tail-end farmers as compared to head-end farmers has been pointed out to be the highest for India and Pakistan (11 and 6\%, respectively).

\section{Groundwater model calibration results}

Calibration statistics for the model indicate a residuals range from -2.918 to $+3.049 \mathrm{~m}$, with a mean of $-0.0536 \mathrm{~m}$ and an absolute residual mean of $0.535 \mathrm{~m}$. The ratio of residual standard deviation $(0.702 \mathrm{~m})$ to the observed range in head $(91.303 \mathrm{~m})$ is 0.77 percent. Heads at 1326 observations out of a total 1568 targets $(84.6 \%)$ are within $\pm 1 \mathrm{~m}$ of observed values and at 1557 out of 1568 targets $(99.3 \%)$ are within $\pm 2 \mathrm{~m}$ of observed values. 
Fig. 10 Increase in groundwater pumping cost with decline in watertable

Fig. 11 Model computed versus observed groundwater elevations
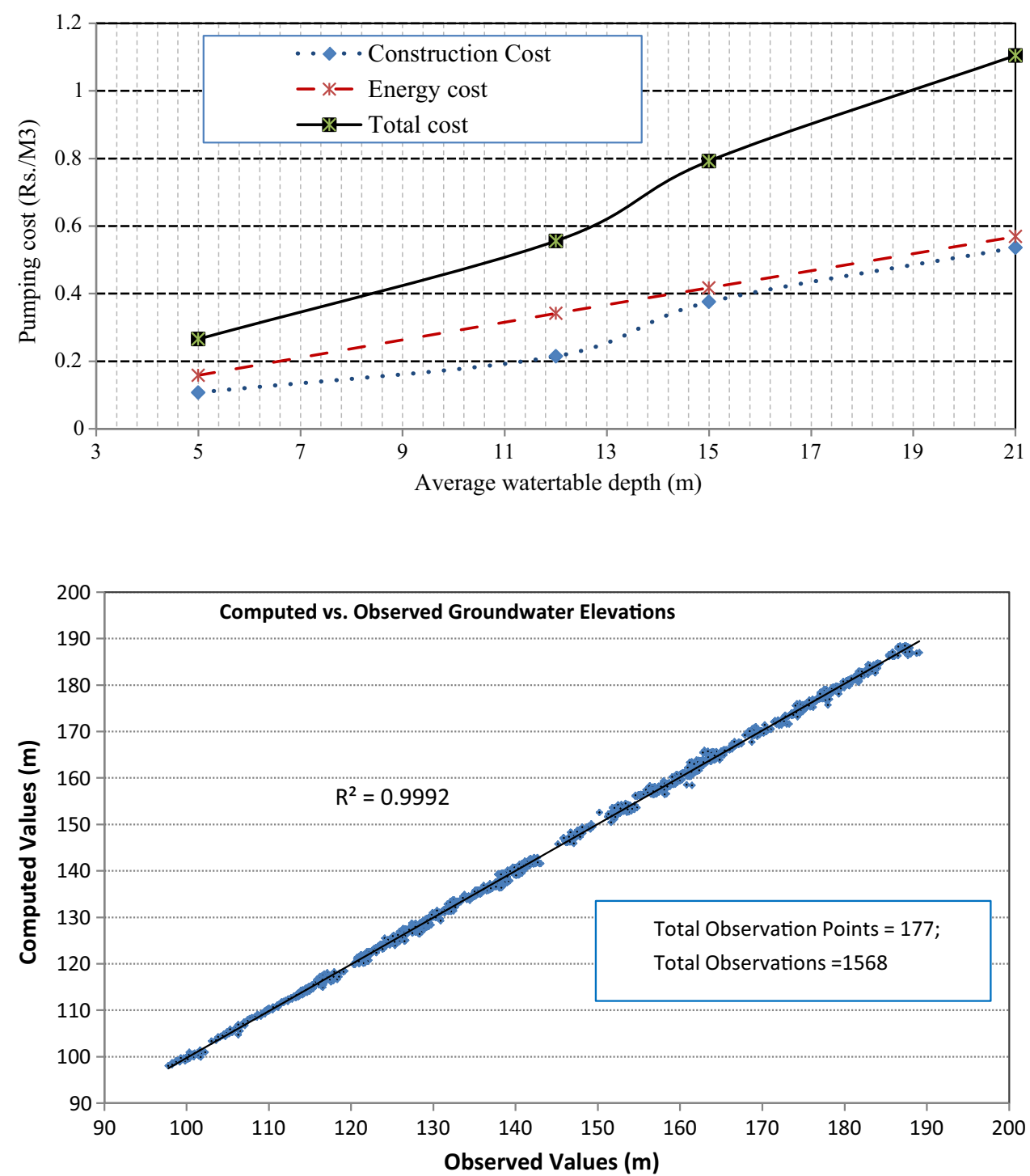

Therefore, heads are reasonably well simulated in the model domain. Model computed versus field observed heads is plotted in Fig. 11, whereas Fig. 12, which is the output of Groundwater Vistas software, shows plot of residual heads against the observed groundwater elevations.

Sources of error in the comparison of model calculated heads with the observed heads include errors in the original reported well locations and measured depths to watertable. Mostly, the monitoring time by the concerned officials is dependent upon availability of funds and therefore, a delay of one to 3 months from the scheduled time (June and October) is a normal practice. Similarly, the errors can also be due to instant pumping impact on groundwater levels by a nearby farmer's tubewell if any, whenever the monitoring time and tubewell operation coincide. Additional possible errors are those in converting well locations to projected coordinates, in overlaying these on an un-projected model grid, and in converting depth to watertable to groundwater elevations, with the natural surface elevation values from SRTM data (90 $\mathrm{m}^{2}$ spatial resolution).

\section{Water level contours}

A comparison of the model simulated and observed spatial distribution of groundwater levels shows how well the model replicates the spatial variation of the interpolated observations. Simulated groundwater elevation contours superimposed on observed groundwater elevation contours for June 2008 (Fig. 8b) show that calibrated model satisfactorily reproduced the spatial distribution of groundwater levels. The model reproduces the interpreted direction of the groundwater flow and closely approximates water 
Fig. 12 Model output for observed groundwater elevations and corresponding residuals

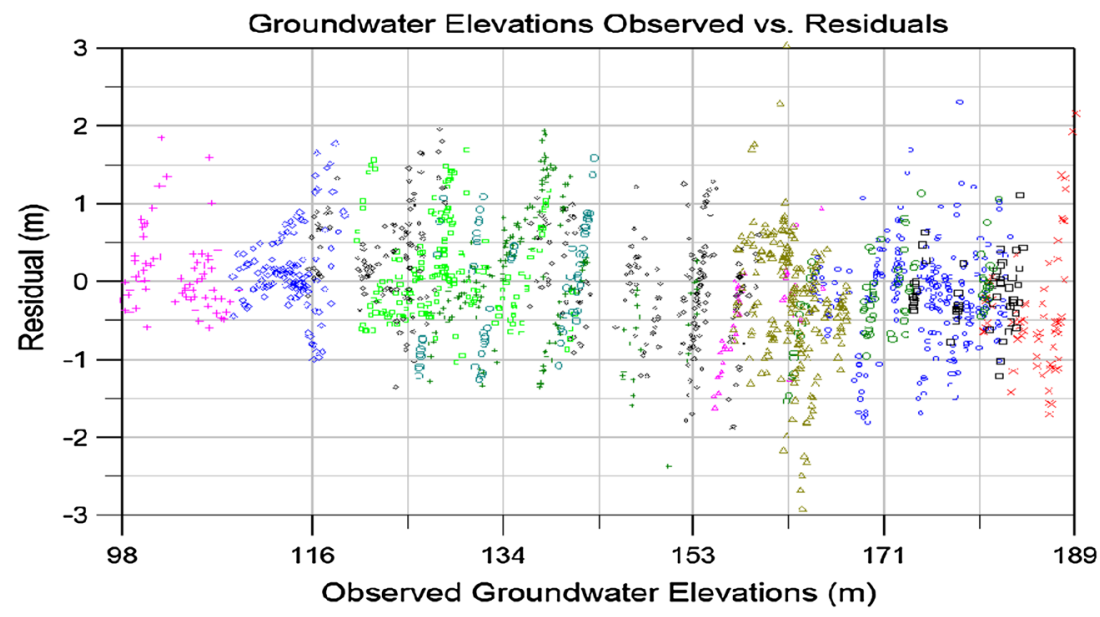

levels in most of the study area and there is no systematic over or under prediction of heads.

\section{Water balance}

According to the mass balance for the entire domain from 2001 to 2009, total recharge (including groundwater returns) for 8.5 years is $23.45 \mathrm{MAF}$ and tubewell abstraction is 27.02 MAF. Values per year for these two parameters are 2.759 and 3.178 MAF, respectively, showing that groundwater abstraction is higher than the recharge to the aquifer. The groundwater budget component due to evaporation is relatively less due to watertable being deep in most of the command areas. It was due to low canal supplies during the modelled period. The minimum and maximum volumetric computation error was 0.0003 and $0.005 \%$, respectively.

\section{Simulation of groundwater levels and impact on irrigation cost}

This paper is limited to the simulation of the impact of prevailing equitable canal water supplies on groundwater depth and the ensuing increases in pumping costs and resulting total irrigation cost towards the tail of the command. Canal water reallocation, with increased canal supplies towards the tail end, with the objectives of equitable total irrigation costs (both from canal and groundwater) was also simulated using this model; the results indicating the most plausible reallocation percentages, from head end towards the tail end, are given in Basharat and Tariq (2014). However, in all these simulations, existing cropping intensities and cropping patterns are assumed to be prevailing in the times to come, i.e., crop water requirements were assumed to be remaining at the existing level. Similarly, any changes induced by climate change or rising energy costs were not considered. The arising inequity regarding groundwater levels and composite irrigation costs is discussed below.

\section{Groundwater levels}

Temporal trends regarding average depth to watertable on HSU basis, as simulated by the model for currently available canal supplies for the last 10 years period (2001-2011) repeated for another 20 years period i.e., up to 2031, are shown Fig. 13. The simulation has also shown persistence of an increasing trend in groundwater depletion towards tail end of the LBDC command. On the contrary, the situation is stable for the first HSU i.e., 1_Balloki_Shergarh and relatively stable for HSU 2_Gugera_Okara and HSU-7 i.e., Abdul Hakeem (due to presence of Sidhnai Barrage and Sidhnai Canal which act as source of recharge). For all other HSUs there is groundwater depletion trend, however, successively increasing towards the tail-end HSUs. Overall, there is a depletion of $8-11 \mathrm{~m}$ in the lower half of the command (i.e., from Chichawatni to Jhanian HSUs) within a period of next 20 years. On an average, groundwater depletion of about $0.30-0.6 \mathrm{~m}$ per year was simulated by these areas. This is due to increasing crop water demand and decreasing rainfall towards the tail end of the command, and the prevailing equitable canal water allocations, ignoring the increasing climate aridity in the downstream direction.

\section{Composite cost inequity}

Certainly, this increasing depth to groundwater in tail-end areas will require extra energy for groundwater pumping. In addition, the tail-end farmers would have to deepen their wells for them to remain functional. Obviously, total irrigation cost would be increasing with passage of time, due to increasing depth to groundwater and ensuing increase in pumping costs. Total irrigation cost incurred by the farmer 
Fig. 13 HUS wise temporal trends of average DTW as simulated by the model with C-2 scenario

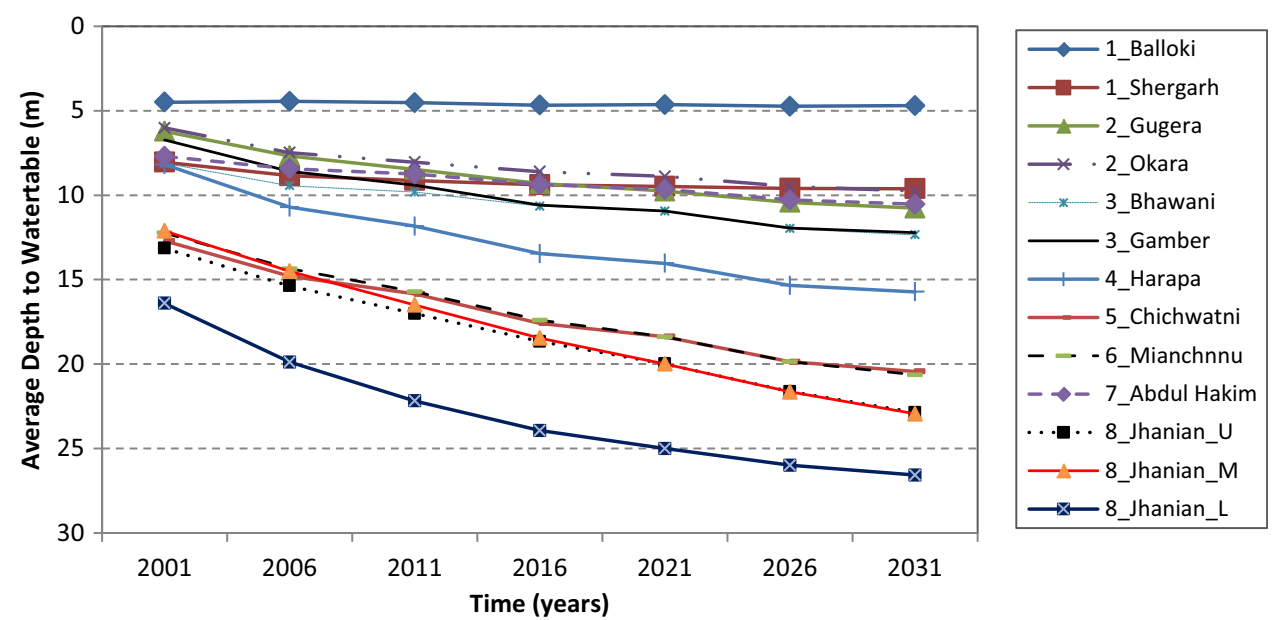

Fig. 14 Total irrigation cost difference amongst the HSUs in years 2011 and 2031

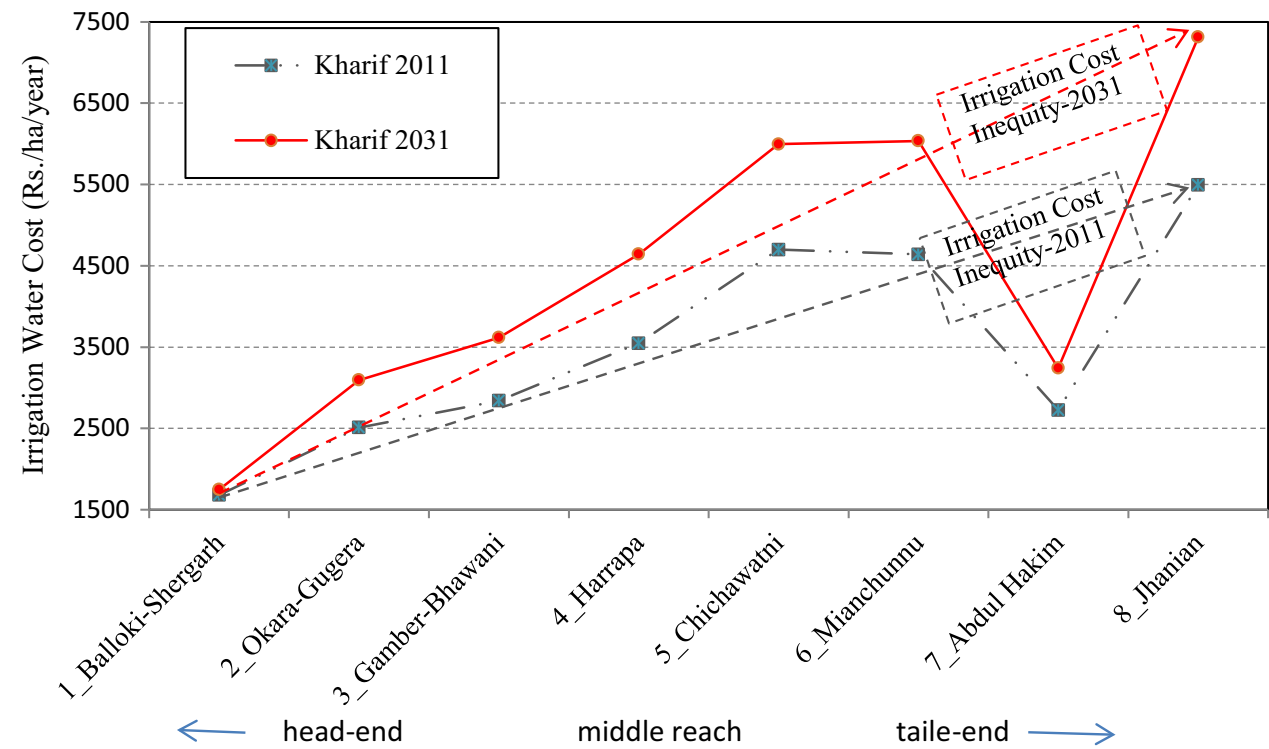

(per hectare per year) on canal water use and groundwater pumping are compared on HSU basis in head-tail perspective. Composite cost of water use from canal water and groundwater for Kharif 2011 and Khraif 2031 is compared in Fig. 14 on HSU basis, showing that there is an increasing trend in irrigation costs towards tail end with passage of time. For Kharif 2011, representing current situation, groundwater use in HSU_8 (tail end) is 1.09 times higher than at HSU_2 (head end). Groundwater pumping cost is 2.37 times higher and the combined cost for groundwater and canal water use is 2.19 times higher for HSU_8 (tail end) as compared to the HSU_2 (head end). According to the simulation till 2031, comparative cost of groundwater pumping alone and combined cost of canal and groundwater use further increase from 2.37 to 2.53 and 2.19 to 2.36 times, respectively from 2011 to 2031 . This is due to higher groundwater depletion rates towards tail end of the command with prevailing equitable canal supplies. Thus, a farmer in HSU_8 has extra expenses of Rs. 2981 and 4215 per hectare as compared to a farmer in HSU_2 as irrigation water cost as on 2011 and 20 years later (2031), respectively.

\section{Conclusions and recommendations}

With the prevailing equitable canal supplies and increasing climate severity in the downstream direction, groundwater recharge from canal supplies and rainfall reduces from $430 \mathrm{~mm}$ at head end to $285 \mathrm{~mm}$ at tail end. Cost per cubic metre of pumped groundwater increases about 3.5 times as the depth to watertable drops from 6 to $21 \mathrm{~m}$ from head to tail in LBDC command. Thus, decreasing rainfall and increasing crop water requirement towards the tail end, and 
equitable canal supplies are causing inequity of total irrigation costs in head-tail end perspective, which otherwise would have been equitable by virtue of equitable canal supplies.

In addition, with existing equitable canal supplies, there is an average depletion of $8-11 \mathrm{~m}$ in the lower half of the command (about $0.30-0.45 \mathrm{~m}$ per year on an average) within a period of next 20 years. At present, groundwater pumping cost is 2.37 times higher and the combined cost for groundwater and canal water use is 2.19 times higher for HSU_8 (tail end) as compared to the HSU_2 (head end). With this equitable canal water distribution, the comparative cost of groundwater pumping alone and the combined cost of canal and groundwater use are expected to further increase from 2.37 to 2.53 and 2.19 to 2.36 times, respectively, from 2011 to 2031 . Thus, the prevailing difference in irrigation costs in head-tail end perspective is expected to further exacerbate with passage of time, if no steps are taken to revert this inequity due to spatial climate variability.

The irrigation system design and operation are based on the principles framed since the system inception, about 100 years back, when contribution of groundwater in comparison to canal water was almost negligible. Now the groundwater contribution is almost at par with canal water in meeting crop consumptive use. Therefore, due to prevailing spatial climate in the area, a farmer at the head end of the command is enjoying less crop water requirement as well as less cost on groundwater pumping as compared to a farmer at the tail end, with higher groundwater requirement and a larger pumping cost per unit volume. In this regard, Bredehoeft (2011) has very clearly declared that "more effective conjunctive management can probably only be accomplished by an approach that integrates the groundwater and surface water into a single institutional framework; they must be managed together to be efficient." Foster and Steenbergen (2011) discussed more bluntly that in many alluvial regions, the authority and capacity for water resources management are mainly retained in surface water-oriented agencies, because of the historical relationship with the development of irrigated agriculture.

Therefore, irrigation planning and management institutions in Pakistan must re-orient the irrigation system operations towards conjunctive use of surface and groundwater, at irrigation system scale. The only choice for handling such kind of situation is to reallocate canal water supply keeping in view the rainfall patterns and consequent crop water requirements. This will certainly improve the equity of groundwater availability and total irrigation cost to the farmers, irrespective of their location in the system.

Acknowledgments The authors are thankful to Punjab Irrigation Department, SCARPs Monitoring Organization of WAPDA and Pakistan Meteorological Department for providing their valuable data sets used in the study. The field data collection was funded by Centre of Excellence in Water Resources Engineering (for Ph.D. research), which is also thankfully acknowledged. Invaluable and extremely productive contributions from researcher colleagues in the form of reviews and discussions are also gratefully acknowledged.

\section{References}

Ahmad N (1995) Groundwater resources of Pakistan (Revised), 16B/2 Gulberg-III, Lahore

Ahmad N, Chaudhry GR (1988) Irrigated agriculture of Pakistan. 61-B/2, Gulberg III, Lahore, Pakistan

Basharat M (2012) Integration of canal and groundwater to improve cost and quality equity of irrigation water in a canal command. Ph.D. thesis, Centre of Excellence in Water Resources Engineering, University of Engineering and Technology, Lahore, Pakistan

Basharat M, Tariq AR (2013a) Long-term groundwater quality and saline intrusion assessment in an irrigated environment: a case study of the aquifer under LBDC irrigation system. Irrig Drain. doi:10.1002/ird.1738

Basharat M, Tariq AR (2013b) Spatial climatic variability and its impact on irrigated hydrology in a canal command. Arab J Sci Eng 38(3):507-522. doi:10.1007/s13369-012-0336-9

Basharat M, Tariq AR (2014) Command scale integrated water management in response to spatial climate variability in LBDC irrigation system. Water Policy J 16(2):374-396. doi:10.2166/ wp. 2013.221

Basharat M, Ali SU, Azhar AH (2014) Spatial variation in irrigation demand and supply across canal commands in Punjab: a real integrated water resources management challenge. Water Policy J 16(2):397-421. doi:10.2166/wp.2013.060

Bennet GD, Rehman A, Sheikh IA, Ali S (1967) Analysis of aquifer tests in Punjab region of West Pakistan. US Geological Survey Water Supply Paper 1608-G, p 56

Bhutta MN, Vander Velde EJ (1992) Equity of water distribution along secondary canals in Punjab, Pakistan. J. Irrig Drain Syst 6:161-177

Bredehoeft J (2011) Hydrologic trade-offs in conjunctive use management. Ground Water 49(4):468-475. doi:10.1111/j. 1745-6584.2010.00762.x

Cheema MJM, Immerzeel WW, Bastiaanssen WGM (2014) Spatial quantification of groundwater abstraction in the irrigated indus basin. Groundwater 52:25-36. doi:10.1111/gwat.12027

Foster S, Steenbergen Van F (2011) Conjunctive groundwater use-a lost opportunity for water management in the developing world? IAH Hydrogeol J 19:959-962. doi:10.1007/s10040-011-0734-1

Halcrow (2006) Punjab irrigated agriculture development sector project, final report Annex 5-groundwater management. Asian Development Bank TA-4642-PAK

Hussain I (2005) Pro-poor intervention strategies in irrigation agriculture in Asia: poverty in irrigated agriculture-issues, lessons, options and guidelines. International Water Management Institute and Asian Development Bank, Colombo

Kumar V, Anandhakumar KJ, Goel MK, Das P (2009). Trends and sustainability of groundwater in highly stressed aquifers. In: Proceedings of symposium JS.2 at the Joint IAHS \& IAH Convention, Hyderabad, India, September 2009. IAHS Publ. 329, 2009, pp 254-263

Latif M (2007) Spatial productivity along a canal irrigation system in Pakistan. J Irrig Drain 56(5):509-521. doi:10.1002/ird.320

Latif M, Ahmad MZ (2009) Groundwater and soil salinity variations in a canal command area in Pakistan. J Irrig Drain 58(4):456-468 
Maupin MA (1999) Methods to determine pumped irrigation-water withdrawals from the Snake River between upper Salmon fall and Swan falls dams, Idaho, using electrical power data, 1990-95. US Geological Survey Water-Resources Investigation Report 99-4175, pp 20

Mirza GM, Latif M (2012) Assessment of current agro-economic conditions in Indus Basin of Pakistan. In: Proceedings of International conference on water, energy, environment and food nexus: solutions and adaptations under changing climate

Nels R, Thomas H, Alec N (2004) Estimation of groundwater pumping as closure to the water balance of a semi-arid, irrigated agriculture basin. J Hydrol 297:51-73 ISSN 0022-1694

NESPAK (2005) Punjab irrigated agriculture development sector project. Water and agricultural sector project. Water and agricultural studies. Lower Bari Doab Canal Command

NESPAK/SGI (1991) Contribution of private tubewells in the development of water potential. National Engineering Services of Pakistan and Special Group Inc., Lahore, prepared for Planning and Development Division, Ministry of Planning and Development, Islamabad

PPSGDP (1998) Canal seepage analysis for calculation of recharge to groundwater, Technical report no. 14, prepared by groundwater modelling team of Punjab Private Sector Groundwater Development Project Consultants

PPSGDP (2000) Draft technical report no. 45, groundwater management and regulation in Punjab, prepared by groundwater modelling team of Punjab Private Sector Groundwater Development Project, Project Management Unit, Irrigation and Power Department, Government of Punjab
Qureshi AS, Akhtar M (2003) Effect of electricity pricing policies on groundwater management in Pakistan. Pak $\mathrm{J}$ Water Resour $7(2): 1-9$

Ritzema HP (1994) Drainage principles and applications, ILRI Publication 16, Second Edition

Shah T (2006) Groundwater and human development: challenges and opportunities in livelihoods and environments. In: Proceedings of IWMI-ITP-NIH International Workshop on creating synergy between groundwater research and management in South and Southeast Asia 8-9 February 2005, India

Steenbergen Van F, Olienmans W (1997) Groundwater resources management in Pakistan, In: ILRI Workshop: groundwater management: sharing responsibilities for an open access resource, proceedings of the Wageningen Water Workshop

US Department of the Interior (1967) Geological survey, water supply paper 1608-H, Plate 6, 1967. US Government Printing Office, Washington, DC 20402

US Army Corps of Engineers (1999) Engineering and design, groundwater hydrology by, US Army Corps of Engineers, Department of the Army Washington, DC 20314-1000

WAPDA (1980a) Hydrogeological data of Bari Doab, Volume-1, basic data release no. 1 by directorate general of hydrolgeology. WAPDA, Lahore

WAPDA (1980a) Lower Rechna remaining project report (SCARP V). Volume I and II Publication No. 27

WMED (1999) Evaluation of conveyance efficiency of lined and unlined watercourses at FESS by watercourse monitoring and evaluation directorate. WAPDA, Lahore 